\title{
PENGARUH STRUKTUR KEPEMILIKAN TERHADAP KEUNGGULAN DAYA SAING BERKELANJUTAN BERDASARKAN REPUTASI UKURAN AKUNTANSI BUMN TbK INDONESIA
}

\author{
Tona Aurora Lubis ${ }^{1}$ \\ Wirmie Eka Putra ${ }^{2}$
}

Jurusan Manajemen Fakultas Ekonomi Universitas Jambi ${ }^{1}$
Jurusan Akuntansi Fakultas Ekonomi Universitas Jambi ${ }^{2}$

Abstract

This study aims to find and analyze models of the effect of ownership structure on the sustainable competitive advantage based on the reputation of the size of the accounting Indonesia's privatized SOEs. The sample of this study a total of 14 SOEs Tbk Indonesia. Analysis of the data in this study using the Partial Least Square (PLS). Results penelitain found that increasing public ownership in the ownership structure of Indonesia's privatized SOEs to improve sustainable competitive advantage based on the reputation of the accounting measure of increased return on equity (ROE), an increase in return on assets (ROA), an increase in the actual dividend payout ratio (ADPR).

Keywords: privatization, ownership structure, reputation accounting size, partial least square

Menurut D’Souza, Megginson, dan Nash, (2006), privatisasi didefinisikan sebagai "as the sale of previously state-owned enterprises to private owners". Definisi tersebut memberikan pemaknaan bahwa privatisasi menyebabkan perubahan kepemilikan pada suatu Badan Usaha Milik Negara (BUMN). Perubahan tersebut berupa awalnya kepemilikan sepenuhnya dikuasai negara menjadi sebagian atau bahkan sepenuhnya menjadi milik publik. 
Latar belakang dilakukannya perubahan struktur kepemilikan tersebut umumnya adalah untuk meningkatkan kinerja BUMN yang dinilai rendah selama dalam kepemilikan pemerintah secara penuh. Gunasekarage, Hess dan Hu (2007) berpendapat bahwa kepemilikan pemerintah lebih lemah dibandingkan kepemilikan swasta dalam pasar persaingan. Hal ini dikarenakan: (i) keberpihakan pemerintah terhadap tujuan sosial dan politik bertentangan dengan tujuan maksimalisasi nilai, (ii) penunjukkan manajemen dan pegawai cenderung memprioritaskan orang-orang yang memiliki pengaruh politik daripada kemampuan berkinerja, dan (iii) biaya transaksi lebih tinggi. De Alessi (1980), Bennett dan Johnson (1980) mempunyai pandangan bahwa perusahaan swasta akan berkinerja lebih baik dibandingkan perusahaan yang dimiliki pemerintah.

Privatisasi BUMN telah menjadi fenomena utama di negara maju dan negara berkembang. Hal tersebut menyebabkan perubahan signifikan pada struktur kepemilikan perusahaan-perusahaan di seluruh dunia (Boubakri, Cosset, Guedhami, 2005). Berdasarkan hal tersebut, D’Souza, Nash, dan Megginson (2005) berpendapat bahwa perubahan mendasar akibat dari privatisasi adalah perubahan kepemilikan.

Menurut D'Souza, et al. (2006), perubahan kepemilikan menyebabkan perubahan tata kelola perusahaan (corporate governance). D'Souza, et al. (2006) juga menyatakan bahwa perubahan tata kelola perusahaan merupakan determinan penting bagi kinerja perusahaan pasca privatisasi. Boubakri, et al. (2005) berpendapat bahwa keberhasilan privatisasi bergantung pada efektifitas mekanisme tata kelola perusahaan pasca privatisasi. Menurut Jensen dan Meckling (1976), struktur kepemilikan memiliki kaitan dengan tata kelola perusahaan sehingga berpengaruh positif atau negatif terhadap tata kelola perusahaan. De Alessi (1995) berpendapat bahwa struktur kepemilikan mempengaruhi dorongan untuk mengejar strategi maksimalisasi nilai.

Struktur kepemilikan BUMN Tbk terdiri atas kepemilikan negara dan kepemilikan publik. Kemungkinan kepemilikan dari kepemilikan publik berupa kepemilikan oleh pegawai, kepemilikan asing, kepemilikan institusi, kepemilikan managerial, dan kepemillikan lainnya. Berdasarkan resource-based view of the firm (RBV), reputasi perusahaan termasuk dalam kategori intangible asset (Michalisin, Smith, dan Klein, 1997). Barney (1991) menyatakan bahwa reputasi perusahaan merupakan salah satu elemen kunci dari intangible resources yang menjadi sumber penciptaan kondisi keunggulan daya saing berkelanjutan (sustainable competitive advantage) bagi suatu perusahaan. Barney (1991) menyebutkan bahwa sebuah perusahaan akan memiliki keunggulan daya saing berkelanjutan ketika perusahaan tersebut menerapkan strategi penciptaan nilai yang tidak diterapkan oleh para pesaing di waktu yang bersamaan, dan ketika perusahaan lain tidak mampu meniru kelebihan dari strateginya. 
Reputasi perusahaan yang baik merupakan sumberdaya langka dan berharga, serta merupakan sumber dari keunggulan daya saing untuk mendapatkan above average return (Barney, 1991). Jika perusahaan memiliki status reputasi di atas rata-rata, maka perusahaan dapat mencapai superior profit (Dowling, 2001). Lubis (20010) menyimpulkan bahwa keunggulan daya saing berkelanjutan dapat dicapai ketika perusahaan menerapkan strategi penciptaan nilai yang tidak mampu diikuti oleh pesaing. Salah satu cara untuk mencapai keunggulan daya saing berkelanjutan tersebut adalah melalui reputasi ukuran akuntansi.

Berdasarkan penelitian-penelitian terdahulu mengenai struktur kepemilikan, dan keunggulan daya saing memunculkan beberapa research gap. Pengaruh kepemilikan publik terhadap keunggulan daya saing sangat penting tetapi belum banyak diteliti. Penelitian ini mengkaji pengaruh struktur kepemilikan terhadap keunggulan daya saing berkelanjutan berdasarkan reputasi ukuran akuntansi pada BUMN Tbk di Indonesia. Mengingat pentingnya privatisasi bagi bangsa Indonesia dan dalam rangka pengembangan literatur, studi ini menjadi penting dan menarik sehingga layak untuk dilakukan penelitian. Secara umum, penelitian ini bertujuan untuk memprediksi model pengaruh struktur kepemilikan terhadap keunggulan daya saing berkelanjutan berdasarkan reputasi ukuran akuntansi pada BUMN Tbk sebagai bukti privatisasi di Indonesia.

\section{Struktur Kepemilikan (Ownership Structure)}

Privatisasi mengakibatkan terjadinya perubahan struktur kepemilikan perusahaan. Menurut Ping (2004), struktur kepemilikan memiliki dua implikasi. Pertama, struktur kepemilikan itu sendiri, yaitu komposisi persentase saham yang dimiliki oleh masing-masing pihak dalam sebuah struktur kepemilikan perusahaan, seperti persentase kepemilikan negara, persentase kepemilikan badan hukum atau institusi, persentase saham perorangan dan persentase lainnya. Kedua, konsentrasi kepemilikan, yaitu kepemilikan persentase saham yang dipegang oleh 5 atau 10 pihak pemegang saham tertinggi.

Jensen dan Meckling, (1976) menyatakan bahwa ketika pemilik tidak mengelola sendiri perusahaannya, konflik kepentingan muncul diantara pemilik dan manajer (agen). Boubakri, et al. (2005) menambahkan bahwa tata kelola perusahaan dimaknai sebagai respon terhadap masalah agensi yang muncul dari pemisahan kepemilikan dan kendali perusahaan. Masalah pengawas-agen yang standar muncul ketika pemilik perusahaan (pengawas) tidak sama dengan manajer yang mengendalikan perusahaan (agen). Masalah ini seringkali diajukan untuk menjelaskan kinerja BUMN yang buruk.

Berkaitan dengan privatisasi, Shleifer dan Vishny (1997) berpendapat bahwa mekanisme tata kelola di negara berkembang biasanya lemah dan bisa mempengaruhi kinerja perusahaan terprivatisasi. Menurut Shleifer dan Vishny (1997), dan 
Boubakri, et al. (2005), literatur umumnya membedakan dua jenis mekanisme tata kelola perusahaan yaitu internal dan ekstrenal. Mekanisme internal mencakup struktur kepemilikan perusahaan. Perubahan kepemilikan dalam konteks privatisasi mampu memunculkan peningkatan kinerja pasca privatisasi. Mekanisme eksternal mencakup tata kelola perusahaan meliputi monitoring pasar modal dan sistem hukum, institusi, serta pasar tenaga kerja.

D'Souza, et al. (2006) menyatakan bahwa perubahan kepemilikan mengakibatkan perubahan tata kelola perusahaan (corporate governance). Menurut Siebens (2002), tata kelola perusahaan adalah pengetahuan dan seni untuk menyeimbangkan pembagian kepentingan dari semua stakeholder dan membuat pilihan diantara beragam opsi dengan dukungan segala jenis informasi untuk menjadi perusahaan yang bertanggung jawab. Husnan (1999) menyatakan bahwa masalah tata kelola perusahaan dapat ditelusuri melalui pengembangan agency theory, yaitu teori yang mencoba menjelaskan bagaimana pihak-pihak yang terlibat dalam perusahaan seperti pengelola/manajer, pemilik perusahaan, dan kreditor akan berperilaku berdasarkan kepentingan yang berbeda-beda.

\section{Keunggulan Daya Saing Berkelanjutan Berdasarkan Reputasi Ukuran Akuntansi}

Menurut Caloghirou (2004), dalam Baaij, Greeven, dan Dalen (2004), literatur mengenai keunggulan daya saing berkelanjutan (Sustainable Competitive Advantage, SCA) didominasi oleh dua perspektif, yaitu ekonomi organisasi industri (oleh Porter, 1985) dan pandangan berbasis sumberdaya perusahaan (oleh Barney, 1991). Menurut ekonomi organisasi industri, keunggulan daya saing berkelanjutan didasarkan pada penentuan posisi strategis perusahaan dalam suatu industri. Berdasarkan pandangan berbasis sumberdaya, keunggulan daya saing berkelanjutan didasarkan pada meng-ekonomis-kan kompetensi inti perusahaan. Kompetensi inti perusahaan tersebut berupa: valuable (yang sangat bernilai), rare (jarang), difficult to imitate (sulit ditiru), trade (diperdagangkan), dan subsitute (digantikan), yang kesemuanya itu kemudian membentuk landasan dari keunggulan daya saing berkelanjutan. Pandangan berbasis sumberdaya memaknai perusahaan sebagai sekumpulan sumberdaya dan kapabilitas yang ketika digabungkan menjadi sumber dan pemasukan ekonomi dan keunggulan daya saing yang berkelanjutan (Barney, 1991).

Barney (1991) mengklasifikasikan sumberdaya menjadi 2 kategori, yaitu tangible dan intangible. Sumberdaya tangible terdiri atas semua item fisik yang dimiliki organisasi, seperti fasilitas, bahan mentah dan peralatan lainnya. Sumberdaya intangible terdiri atas semua item yang tidak terlihat pada buku neraca seperti budaya organisasi, reputasi, dan kontrol internal. Sumberdaya tangible bersifat fleksibel, dan bisa lebih mudah ditiru dibanding sumberdaya intangible, yang menurut maknanya tidak fleksibel (Chatterjee dan Wernerfelt, 1991). Sumberdaya intangible 
selalu dianggap memainkan peran penting dalam penciptaan nilai perusahaan dan keunggulan daya saing. Hal ini didukung oleh penelitian Teece (2000) yang menunjukkan bahwa kinerja superior perusahaan bergantung pada kemampuannya berinovasi, mempertahankan aset intangible (yakni, pengetahuan), dan menggunakan aset tersebut.

Menurut pandangan berbasis sumberdaya perusahaan (the resource-based view of the firm (RBV)), landasan keunggulan daya saing berkelanjutan perusahaan muncul dari kemampuannya seperti nilai, kelangkaan, sulitnya ditiru, dan organisasi (Barney, 1991). Istilah yang lebih umum adalah inovasi, arsitektur, dan aset strategis serta reputasi (Kay, 1995). Menurut Rose dan Thomsen (2004), manajemen di perusahaan besar menggunakan sebagian besar sumberdaya dan usahanya untuk mempertahankan dan meningkatkan reputasi perusahaannya, yang sangat penting bagi keberhasilan dan kelangsungan perusahaan.

Reputasi perusahaan dapat ditinjau dari berbagai sudut pandang sehingga memiliki sejumlah definisi yang berbeda satu sama lain. Menurut Dobson (1989), reputasi perusahaan didefinisikan sebagai suatu behavioral trait yang dibangun oleh serangkaian kegiatan yang konsisten. Reputasi yang terbentuk akan meningkatkan nilai perusahaan secara implisit dan dapat dijual kepada stakeholders-nya. Weigelt dan Camerer (1988) menunjukkan bahwa reputasi perusahaan merupakan serangkaian atribut perusahaan yang diperoleh dari kegiatan-kegiatan yang telah dilakukan dimasa lalu.

Menurut Barney (1991), reputasi perusahaan merupakan salah satu elemen kunci dari intangible resources yang akan menjadi sumber penciptaan kondisi keunggulan daya saing berkelanjutan bagi suatu perusahaan. Reputasi juga merupakan suatu konsep yang kompleks. Barney menyatakan "Reputation will win or lost, be created as a result of many activities of the corporation that go beyond the consideration of interest". Menurut Rose dan Thomsen (2004), reputasi perusahaan yang baik memiliki karakteristik aset intangible dan ini bisa memberi perusahaan keunggulan daya saing yang karenanya menghasilkan return di atas normal.

Penelitian Suta (2006) menegaskan bahwa reputasi perusahaan dibangun atau dibentuk dari faktor-faktor pembentuk reputasi perusahaan. Faktor-faktor yang membentuk reputasi perusahaan tersebut adalah reputasi corporate governance, reputasi CEO (Chief Executive Officer), dan reputasi social responsibility (tanggungjawab sosial), serta reputasi accounting measures (ukuran-ukuran akuntansi).

Faktor ukuran akuntansi, menurut Brigham, Eugene dan Houston (2004), dibagi menjadi 5 kategori rasio untuk mengukur kinerja keuangan perusahaan, yaitu rasio likuiditas, manajemen aset, manajemen hutang, keuntungan (profitability), dan nilai pasar (market value). Namun, menurut Suta (2006), para investor umumnya menggunakan empat rasio untuk mengukur kinerja keuangan/akuntansi perusahaan, yaitu pertumbuhan pendapat bersih, imbal hasil investasi atau imbah hasil aset, dan 
imbal hasil ekuitas, serta rasio antara pembayaran deviden aktual dengan total pendapatan. Pertimbangan dalam memilih rasio ROA dan ROE didasari oleh teori Du Pont system. ROA dan ROE merupakan hasil akhir dari perkalian beberapa rasio keuangan.

Lubis (2010) menyimpulkan bahwa melalui proses pemikiran rasional terhadap konsep-konsep mengenai keunggulan daya saing, reputasi, dan ukuran akuntansi, sebuah frasa baru muncul dengan definisi yang menggabungkan tiga konsep tersebut, yaitu keunggulan daya saing berkelanjutan berdasarkan reputasi ukuran akuntansi. Kesimpulannya adalah definisi keunggulan daya saing berkelanjutan berdasarkan reputasi ukuran akuntansi merupakan suatu keadaan ketika sebuah perusahaan memiliki kinerja keuangan/akuntansi yang sangat menguntungkan bagi perusahaan dan sulit untuk dicapai atau ditiru oleh pesaing sehingga superioritas kinerja tersebut menjadi persepsi yang tertanam di benak publik.

Privatisasi BUMN yang dilakukan dengan metode penjualan saham ke pasar modal menjadikan BUMN tersebut menjadi BUMN publik atau terbuka (BUMN Tbk). Struktur kepemilikan BUMN Tbk terdiri dari kepemilikan negara dan kepemilikan publik. Menurut D'Souza, et al. (2005), perubahan yang mendasar sebagai akibat dari privatasasi adalah perubahan kepemilikan. D'Souza, et al. (2006) menyatakan bahwa perubahan kepemilikan mengakibatkan perubahan tata kelola perusahaan (corporate governance) dan perubahan tata kelola perusahaan merupakan determinan penting bagi kinerja perusahaan pasca privatisasi. Boubakri, et al. (2005) berpendapat bahwa keberhasilan privatisasi bergantung pada efektifitas mekanisme tata kelola perusahaan pasca privatisasi. Menurut Jensen dan Meckling (1976), struktur kepemilikan memiliki kaitan dengan tata kelola perusahaan, maka struktur kepemilikan ini memiliki pengaruh baik positif maupun negatif terhadap tata kelola perusahaan. Kaen (2003) menyatakan bahwa prinsip-prinsip tata kelola perusahaan dapat dibagi dalam lima area, yaitu hak-hak pemegang saham, kesetaraan perlakuan kepada pemegang saham, peran pemegang saham, pengungkapan dan transparasi, dan tanggung jawab jajaran direksi.

Berdasarkan resource-based view of the firm (RBV), reputasi perusahaan termasuk dalam kategori intangible asset (Michalisin et al. 1997). Fombrun dan Shanley (1990) menemukan bahwa kinerja historis dan sinyal non-ekonomi lainnya mempengaruhi reputasi. Menurut Barney (1991), reputasi perusahaan merupakan salah satu elemen kunci dari intangible resources yang menjadi sumber penciptaan kondisi keunggulan daya saing berkelanjutan (sustainable competitive advantage) bagi suatu perusahaan.

Suta (2006), dalam penelitiannya, menyimpulkan bahwa tata kelola perusahaan yang baik merupakan faktor penting yang menentukan reputasi perusahaan. Reputasi perusahaan dibangun atau dibentuk dari faktor-faktor pembentuk reputasi perusahaan. Faktor-faktor yang membentuk reputasi perusahaan adalah reputasi corporate governance, reputasi CEO (Chief Executive Officer), dan reputasi social 
responsibility (tanggungjawab sosial), serta reputasi accounting measures (pengukuran akuntansi).

Kesimpulan yang bisa diambil adalah privatisasi dengan metode penjualan saham ke pasar modal menyebabkan terjadinya perubahan struktur kepemilikan berupa adanya kepemilikan publik dalam BUMN Tbk. Perubahan struktur kepemilikan mempengaruhi perubahan tata kelola perusahaan. Perubahan tata kelola perusahaan mempengaruhi keunggulan daya saing berkelanjutan bagi perusahaan. Salah satu pembentuk keunggulan daya saing berkelanjutan adalah reputasi perusahaan. Salah satu pembentuk reputasi perusahaan adalah reputasi ukuran-ukuran akuntansi. Berdasarkan paparan tersebut maka hipotesis kedua yang dapat diajukan dalam penelitian ini adalah: Meningkatnya kepemilikan publik dalam struktur kepemilikan akan mampu meningkatkan keunggulan daya saing berkelanjutan berdasarkan reputasi ukuran akuntansi

\section{METODE}

Penelitian ini merupakan penelitian kuantitatif, berupa penelitian eksplanatoris (explanatory research). Berdasarkan cakupan eksplanasinya, penelitian ini merupakan penelitian kausalitas. Populasi dalam penelitian ini adalah BUMN RI yang diprivatisasi menggunakan metode penjualan saham di pasar modal. Privatisasi yang dilakukan dengan metode penjualan saham di pasar modal melalui Initial Publik Offering (IPO) merubah BUMN tersebut menjadi BUMN publik atau terbuka (BUMN Tbk). Periode populasi penelitian didasarkan sejak BUMN Tbk tersebut melakukan penjualan saham pasar modal hingga tahun 20012.

Sampel penelitian ini ditentukan dengan menggunakan metode purposive sampling tipe judgement sampling. Metode ini digunakan dalam penelitian ini karena kriteria pemilihan sampel didasarkan pada pertimbangan-pertimbangan yaitu; BUMN Tbk sektor industri perbankan dalam penelitian ini tidak diteliti karena memiliki standar akuntansi dan struktur keuangan yang berbeda dengan sektor industri lainnya. Hal ini sesuai dengan penelitian Farinos, García, Ibáñez (2007) dan Naceur, Ghazouani, Omran (2006) yang tidak memasukkan sektor industri perbankan dalam penelitian mereka masing-masing.

Menurut Naceur, et al. (2006) bahwa institusi finansial tidak disertakan dalam penelitian mereka karena perusahaan jenis ini menunjukkan kecenderungan mempertahankan standar akunting dan struktur finansialnya; BUMN Tbk yang memiliki kepemilikan saham pemerintah RI $>51 \%$. Pemilihan ini dilatarbelakangi oleh hingga tahun 2007 terdapat 13 BUMN Tbk yang kepemilikan saham pemerintah RI masih diatas $51 \%$, sedangkan kepemilikan saham pemerintah RI terhadap BUMN Tbk dibawah 51\% hanya ada satu BUMN Tbk yaitu PT Indosat Tbk. Berdasarkan latarbelakang tersebut, maka penelitian ini meneliti secara total BUMN Tbk yang memiliki kepemilikan saham pemerintah RI >51\%; BUMN Tbk yang melakukan 
IPO sebelum tahun 2012 dan mempunyai laporan keuangan hingga tahun 2012. Berdasarkan kriteria pemilihan sampel penelitian tersebut, maka sampel penelitian yang diperoleh berjumlah 14 (sembilan) BUMN Tbk, secara lengkap dapat dilihat pada tabel berikut:

\section{Tabel 1. Sampel Penelitian}

\begin{tabular}{llcc}
\hline NO & \multicolumn{1}{c}{ BUMN Tbk } & ID & Jenis Perusahaan \\
\hline 1. & PT Semen Gersik Tbk & SMGR & Semen \\
2. & PT Timah Tbk & TINS & Pertambangan Logam dan Mineral \\
3. & PT Telekomunikasi Indonesia Tbk & TLKM & Telekomunikasi \\
4. & PT Aneka Tambang Tbk & ANTM & Pertambangan Logam dan Mineral \\
5. & PT Kimia Farma Tbk & KAEF & Farmasi \\
6. & PT Indofarma Tbk & INAF & Farmasi \\
7. & PT Tambang Batu Bara Bukit Asam Tbk & PTBA & Pertambangan Batu Bara \\
8. & PT Perusahaan Gas Negara Tbk & PGAS & Energi \\
9. & PT Adhi Karya Tbk & ADHI & Konstruksi Bangunan \\
10. & PT Jasa Marga Tbk & JSMR & Jalan Tol, Pelabuhan Udara dan \\
11. & PT Wijaya Karya Tbk & WIKA & Konstruksi Bangunan \\
12. & PT Krakatau Steel Tbk & KRAS & Logam dan Produk Lainnya \\
13. & PT Pembangunan Perumahan Tbk & PTPP & Konstruksi Bangunan \\
14. & PT Garuda Indonesia Tbk & GIAA & Transportasi \\
\hline
\end{tabular}

Sumber: disarikan oleh Peneliti

Analisis data dalam penelitian menggunakan statistik inferensial berupa Partial Least Square (PLS). Penelitian ini menggunakan software SmartPLS versi 1.10.

\section{HASIL}

Hasil analisis statistik inferensial dalam penelitian ini mengikuti langkah-langkah pengujian empiris penelitian berbasis PLS.

\section{Hasil Pengujian Measurement Model (outer model)}

Semua variabel laten dalam penelitian ini mempunyai indikator yang bersifat formatif. Angka-angka di dalam tabel berikut didapatkan melalui hasil running bootstrapping. Tabel result for outer weights ini digunakan untuk mengetahui indikator- indikator dari setiap variabel. Kolom original sample estimate weights menunjukkan nilai outer weight dan nilai $t$-stat yang bersumber dari kolom $t$-stat pada tabel result for outer weights. Indikator dengan outer weight terbesar menunjukkan bahwa indikator tersebut merupakan pengukur variabel yang terkuat (dominan). Nilai $t$-stat di atas 1,96 digunakan untuk mengetahui tingkat signifikansinya. 
Tabel 2. Results for Outer Weight

\begin{tabular}{|c|c|c|c|c|}
\hline & $\begin{array}{c}\text { original sample } \\
\text { estimate }\end{array}$ & $\begin{array}{c}\text { mean of } \\
\text { subsamples }\end{array}$ & $\begin{array}{c}\text { Standard } \\
\text { deviation }\end{array}$ & T-Statistic \\
\hline SK & & & & \\
\hline KTP & 1.000 & 1.000 & 0.000 & \\
\hline KDSBBRUA & & & & \\
\hline ADPR & 0.243 & 0.254 & 0.108 & 2.255 \\
\hline NIG & -0.081 & -0.060 & 0.138 & 0.586 \\
\hline ROA & -0.846 & -0.862 & 0.235 & 3.601 \\
\hline ROE & 1.598 & 1.589 & 0.180 & 8.896 \\
\hline
\end{tabular}

Sumber: hasil bootsrapping running PLS

Berdasarkan tabel 2, indikator KTP memiliki nilai outer weight sebesar 1,000. Angka tersebut menunjukkan bahwa indikator kepemilikan publik sebagai pengukur sangat dominan dan merupakan satu-satunya variabel struktur kepemilikan. Variabel Keunggulan Daya Saing Berkelanjutan Berdasarkan Reputasi Ukuran Akuntansi (KDSBBRUA) memiliki indikator ADPR, NIG, ROA, dan ROE. Indikator ROE, ROA, dan ADPR memiliki t-statatistik yang signifikan, sedangkan NIG tidak signifikan.

\section{Hasil Pengujian Structural Model (inner model)}

Pengujian terhadap structural model (inner model) dilakukan dengan melihat nilai $R$-square sebagai hasil uji goodness-fit model. Nilai $R$-square dapat dilihat di dalam tabel $R$-square dari hasil running calculate model. Pengujian goodness of fit model struktural terhadap inner model menggunakan nilai predictive-relevance $\left(\mathrm{Q}^{2}\right)$. Besaran $\mathrm{Q}^{2}$ memiliki nilai rentang $0<\mathrm{Q}^{2}<1$. Semakin mendekati 1 berarti model semakin baik (Solimun dan Rinaldo, 2009).

$R$-square dalam penelitian dapat dilihat pada tabel berikut ini :

\section{Tabel 3. R Square}

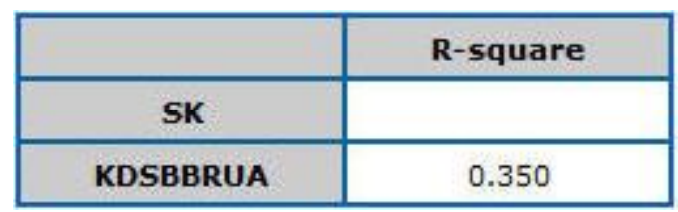

Sumber: hasil calculate running PLS

Berdasarkan tabel 3 tersebut, maka nilai predictive-relevance dapat diperoleh dengan menggunakan formulasi dan perhitungan sebagai berikut:

$\mathrm{Q}^{2}=1-\left(1-\mathrm{R}_{1}^{2}\right)$ 
$\mathrm{Q}^{2}=1-(1-0,350)$

$\mathrm{Q}^{2}=1-(0,65)$

$\mathrm{Q}^{2}=0,35$

Hasil perhitungan nilai predictive-relevance sebesar 0,35 atau 35\% memperlihatkan bahwa keragaman data yang dapat dijelaskan oleh model tersebut adalah sebesar $35 \%$. Sisa $65 \%$ dijelaskan oleh variabel lain yang belum terkandung dalam model dan error.

\section{Hasil Pengujian Hipotesis}

Tabel results for inner weights dari hasil running bootstrapping digunakan untuk mengetahui pengaruh langsung antar variabel dari hipotesis. Nilai $t$-stat yang berada diatas nilai 1,96 menunjukkan pengaruh langsung signifikan dari hipotesis.

\section{Tabel 4. Results for Inner Weights}

\begin{tabular}{|l|c|c|c|c|}
\hline & $\begin{array}{c}\text { original sample } \\
\text { estimate }\end{array}$ & $\begin{array}{c}\text { mean of } \\
\text { subsamples }\end{array}$ & $\begin{array}{c}\text { Standard } \\
\text { deviation }\end{array}$ & T-Statistic \\
\hline SK $\rightarrow$ KDSBBRUA & 0.592 & 0.611 & 0.039 & 15.253 \\
\hline
\end{tabular}

Sumber : hasil bootsrapping running PLS

Selain dengan menggunakan tabel 2 dan tabel 4, hasil penelitian ini dapat juga dilihat dengan menggunakan gambar dari hasil running bootrapping PLS. Berikut gambar dari hasil penelitian ini:

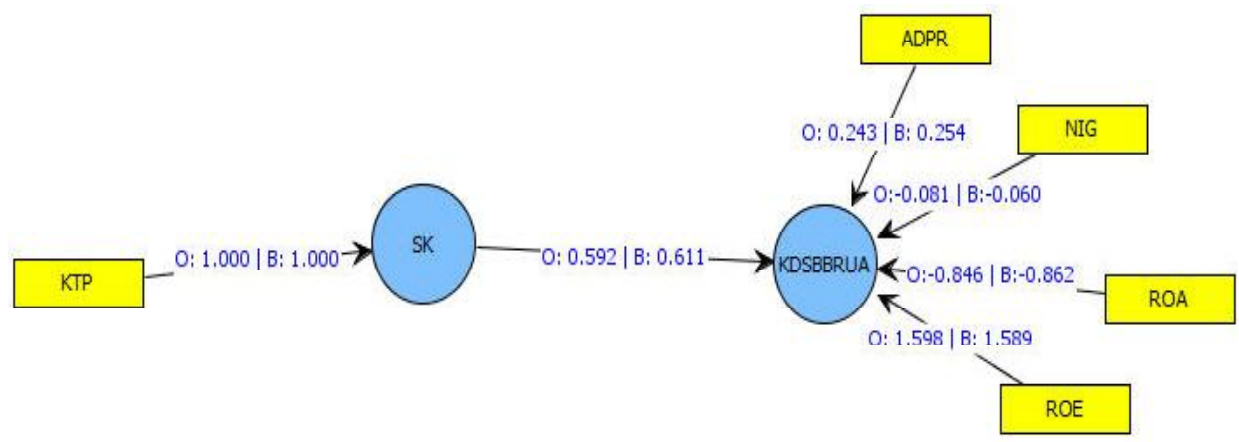

\section{Gambar 1. Hasil Bootsrapping Model Penelitian}

Hipotesis penelitian ini adalah "meningkatnya kepemilikan publik dalam struktur kepemilikan mampu meningkatkan keunggulan daya saing berkelanjutan berdasarkan reputasi ukuran akuntansi'. Berdasarkan Tabel 4 dan Gambar 1, hasil pengujian hipotesis menghasilkan nilai koefisien jalur sebesar 0,592 dan signifikan dengan $t$ stat sebesar 15,253. Hasil tersebut menunjukkan bahwa pengaruh struktur kepemilikan terhadap keunggulan daya saing berkelanjutan berdasarkan reputasi ukuran akuntansi adalah sebesar 0,592 dan signifikan. Kesimpulannya adalah terdapat 
cukup bukti empiris untuk menerima hipotesis yaitu "meningkatnya kepemilikan publik dalam struktur kepemilikan mampu meningkatkan keunggulan daya saing berkelanjutan berdasarkan reputasi ukuran akuntansi”.

\section{PEMBAHASAN}

Hasil penelitian ini menyimpulkan bahwa meningkatnya kepemilikan publik dalam struktur kepemilikan mampu meningkatkan keunggulan daya saing berkelanjutan berdasarkan reputasi ukuran akuntansi. Kepemilikan total publik (KTP) merupakan satu-satunya pembentuk struktur kepemilikan. Sedangkan ROE ROA, ADPR merupakan pembentuk keunggulan daya saing berkelanjutan berdasarkan reputasi ukuran akuntansi. Dengan demikian dapat disimpulkan bahwa meningkatnya kepemilikan publik dalam struktur kepemilikan BUMN Tbk di Indonesia dapat meningkatkan keunggulan daya saing berkelanjutan berdasarkan reputasi ukuran akuntansi berupa peningkatan imbal hasil ekuitas (ROE), peningkatan imbal hasil aset (ROA), peningkatan rasio pembayaran deviden actual (ADPR).

Penelitian ini menunjukkan bahwa pembentuk keunggulan daya saing berkelanjutan berdasarkan reputasi ukuran akuntansi yang paling berpengaruh signifikan secara berurutan adalah imbal hasil ekuitas, imbal hasil aset dan rasio pembayaran deviden actual. Penelitian ini berbeda dengan hasil penelitian Suta (2006) yang meneliti pembentuk reputasi ukuran akuntansi yang paling berpengaruh secara berurutan adalah imbal hasil aset (ROA), imbal hasil ekuitas (ROE), rasio pembayaran deviden aktual, serta pertumbuhan laba bersih.

Teori Du Pont system menjelaskan bahwa ROA dan ROE merupakan hasil akhir dari perkalian beberapa rasio keuangan. Sementara itu, hasil penelitian ini menjelaskan bahwa ROA dan ROE merupakan pembentuk kenggulan daya saing berkelanjutan berdasarkan reputasi ukuran akuntansi. Hasil penelitian ini mengindikasikan secara tersirat bahwa keunggulan daya saing berkelanjutan berdasarkan reputasi ukuran akuntansi juga dibentuk oleh rasio-rasio keuangan.

Lubis (2010) melakukan penelitian pada BUMN Tbk yang melakukan IPO sebelum tahun 2007. Penelitiannya menggunakan sampel sebanyak 9 BUMN Tbk. Hasil penelitiannya menunjukkan bahwa meningkatnya kepemilikan publik dalam struktur kepemilikan BUMN Tbk di Indonesia dapat meningkatkan keunggulan daya saing berkelanjutan berdasarkan reputasi ukuran akuntansi hanya berupa peningkatan imbal hasil ekuitas (ROE). Penelitian ini memperluas periode penelitian yaitu BUMN Tbk tersebut melakukan IPO sebelum tahun 2012. Dengan periode penelitian ini maka sampel penelitian ini berjumlah 14 (empat belas) BUMN Tbk. Hasil penelitian ini konsisten dan memperkuat kesimpulan bahwa meningkatnya kepemilikan publik dalam struktur kepemilikan BUMN Tbk di Indonesia dapat meningkatkan keunggulan daya saing berkelanjutan berdasarkan reputasi ukuran akuntansi. Dengan demikian secara umum dapat disimpulkan bahwa privatisasi 
terbukti mampu meningkatkan kaunggulan daya saing berkelanjutan berdasarkan reputasi ukuran akuntansi BUMN Tbk Indonesia.

\section{KESIMPULAN}

Kesimpulan yang dapat dirumuskan berdasarkan hasil penelitian ini adalah meningkatnya kepemilikan publik dalam struktur kepemilikan BUMN Tbk di Indonesia dapat meningkatkan keunggulan daya saing berkelanjutan berdasarkan reputasi ukuran akuntansi berupa peningkatan imbal hasil ekuitas (ROE), peningkatan imbal hasil aset (ROA), peningkatan rasio pembayaran deviden actual (ADPR).

Berdasarkan hasil penelitian, beberapa saran dapat dirumuskan sebagai berikut: (a) Hasil penelitian menunjukkan bahwa metode privatisasi harus bersifat transparan dan memberikan kesempatan kepada masyarakat untuk ikut memiliki BUMN Tbk. Metode semacam ini akan menumbuhkan rasa nasionalisme dan mendukung distribusi kesejahteraan. Metode privatisasi yang memenuhi kriteria tersebut adalah penjualan saham ke pasar modal. Pengurangan dominasi kepemilikan pemerintah memungkinkan tata kelola BUMN Tbk tersebut tidak lagi dipengaruhi oleh tujuan politik dan sosial yang umumnya bertentangan dengan tujuan maksimalisasi nilai perusahaan. (b) Berdasarkan keterbatasan-keterbatasan penelitian, penelitian ini memberikan peluang munculnya penelitian berikutnya. Peluang bagi penelitian berikutnya adalah: Pertama, penelitian berikutnya dapat meneliti BUMN Tbk berdasarkan sektor industri. Kedua, penelitian berikutnya dapat meneliti BUMN Tbk berdasarkan komposisi pembentuk struktur kepemilikan, seperti kepemilikan managerial, kepemilikan institusi, kepemilikan pegawai, dan lainnya terhadap kinerja BUMN Tbk tersebut

\section{DAFTAR PUSTAKA}

Baaij, M., Greeven, M., Dalen, J.V. 2004. Persistent Superior Economic Performance, Sustainable Competitive Advantage, and Schumpeterian Innovation: Leading Established Computer Firms 1954-2000, European Management Journal 22 (5):517-531.

Barney, J.B. 1991. Firm Resources and Sustaining Competitive Advantage, Journal of Management 17: 99-120.

Bennett, J., Johnson, M. 1980. Tax Reduction without Sacrifice: Private Sector Production of Public Services, Public Finance Quarterly 8: 363-396.

Boubakri, N., Cosset, J.C., Guedhami, O. 2005. Postprivatization Corporate Governance: The Role of Ownership Structure and Investor Protection, Journal of Financial Economics 76: 369-399.

Brigham, E., F. Houston, J.F. 2004. Fundamentals of Financial Management, South Western: Thomson.

Chatterjee, S., Wernerfelt, B. 1991. The Link Between Resources and Type of Diversification: Theory and Evidence, Strategic Management Journal 12:33-48. 
D’Souza, J., Megginson, W., and Nash, R. 2006. The Effects of Changes in Corporate Governance and Restructurings on Operating Performance: Evidence from Privatizations, Global Finance Journal 158.

De Alessi, L. 1995. The Economics of Property Rights: A Review of the Evidence. In Medema, Steven G. (Ed.), The Legacy of Ronald Coase in Economic Analysis, Vol. 2. Intellectual Legacies in Modern Economics Series. Edward Elgar, Aldershot, UK, pp. 242 288.

De Alessi, L. 1980. The Economics of Property Rghts: A Review of the Evidence, Research in Law and Economics 2:1-47.

Dobson, J. 1989. Corporate Reputation: a Free-Market Solution to Unethical Behavior, Business and Society 28: 1.

Dowling, G. 2001. Creating Corporate Reputation, Identify, Image and Performance. New York: Oxford University Press.

Farinós, J.E., García, C.J., Ibáñez, A.M. 2007. Operating and Stock Market Performance of State-owned Enterprise Privatizations: The Spanish Experience, International Review of Financial Analysis.

Fombrun, C., Shanley. 1990. What's in a Name? Reputation Building and Corporate Strategy, Academy of Management Journal.

Gunasekarage, A., Hess, K., dan Hu., A. 2007. The Influence of the Degree of State Ownership and the Ownership Concentration on the Performance of Listed Chinese Companies, Research in International Business and Finance 21:379-395.

Husnan, S. 1999. Corporate Governance di Indonesia: Pengamatan terhadap Sektor Korporat dan Keuangan, Makalah Seminar.

Jensen, M.C., Meckling, W.H. 1976. The Theory of Firm: Managerial Behavior, Agency Cost and Ownership Structure. Journal of Financial Economics, pp. 305-360.

Kaen, F.R. 2003. A Blueprint for Corporate Governance: Strategy, Accountability, and the Preservation of Shareholder Value, Amacom. New York.

Kay, J. 1995. Why Firms Succeed. Oxford: Oxford Univ Press.

Lubis, T.A. 2010. Pengaruh Struktur Kepemilikan Terhadap Kinerja Finansial dan Operasional, Keunggulan Daya Saing Berdasarkan Reputasi Ukuran Akuntansi, dan Kinerja Pasar (Studi Pada BUMN Tbk). Disertasi. Univesitas Brawijaya Malang.

Michialisin, M.D., Smith, R.D., Klien, D.M. 1997. In Search of Strategic Assets, International Journal of Organizational 5 (4):360-387.

Naceur, S.B., Ghazouani, S., Omran, M. 2006. The Performanance of Newly Privatized in Selected MENA Countries: the Role of Ownerships Structure, Governance and Liberalized Policies, International Review of Financial Analysis.

Ping, J. 2004. The Relationship Between Ownership Structure and Firm Performance: an Empirical Analysis Over Heilongjiang Listed Companies, Nature and Science 2: (4).

Rose, C., Thomsen, S. 2004. The Impact of Corporate Reputation on Performance: Some Danish Evidence, European Management Journal 22: No. 2, pp. 201-210.

Shleifer, A., Vishny, R.W. 1997. A survey of corporate governance, Journal of Finance 52: 737-783.

Siebens, H. 2002. Concepts and Working Instrumens for Corporate Governance, Journal of Business Strategy 6 (2): 44-51. 
Solimun, dan Rinaldo, A. 2009. Pemodelan Persamaan Struktural Pendekatan PLS dan SEM Aplikasi Software SmartPLS dan Amos. Laboratorium Statistika FMIPA Universitas Brawijaya Malang.

Suta, I Putu Gede Ary. 2006. Kinerja Pasar Perusahaan Publik di Indonesia:Suatu Analisis Reputasi Perusahaan, Yayasan Sad Satria Bhakti.

Weigelt, K., Camerer, C.F. 1988. Reputation and Corporate Strategy: A Review of Recent Theory and Aplications, Strategic Management Journal 9:443. 